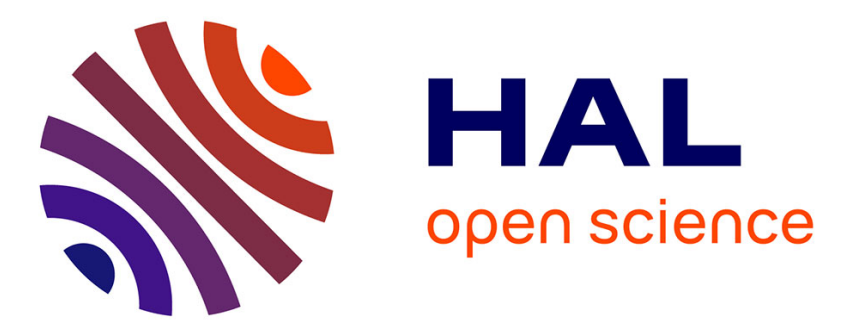

\title{
Review of low pressure plasma processing of proton exchange membrane fuel cell electrocatalysts
}

\author{
Pascal Brault
}

\section{To cite this version:}

Pascal Brault. Review of low pressure plasma processing of proton exchange membrane fuel cell electrocatalysts. Plasma Processes and Polymers, 2016, 13 (1), pp.10. 10.1002/ppap.201500171. hal-01222452

\section{HAL Id: hal-01222452 \\ https://hal.science/hal-01222452}

Submitted on 29 Oct 2015

HAL is a multi-disciplinary open access archive for the deposit and dissemination of scientific research documents, whether they are published or not. The documents may come from teaching and research institutions in France or abroad, or from public or private research centers.
L'archive ouverte pluridisciplinaire HAL, est destinée au dépôt et à la diffusion de documents scientifiques de niveau recherche, publiés ou non, émanant des établissements d'enseignement et de recherche français ou étrangers, des laboratoires publics ou privés. 


\title{
Review of low pressure plasma processing of proton exchange membrane fuel cell electrocatalysts.
}

\author{
Pascal Brault*
}

Dr. P. Brault

GREMI UMR7344 CNRS Université d'Orléans, 14 rue d'Issoudun BP 6744, 45067

ORLEANS, France

E-mail: pascal.brault@univ-orleans.fr

\begin{abstract}
The present review is describing recent advances in plasma deposition and treatment of low temperature proton exchange membrane fuel cells electrocatalysts. Interest of plasma processing for growth of platinum based, non-precious and metal free electrocatalysts is highlighted. Electrocatalysts properties are tentatively correlated to plasma parameters.
\end{abstract}

\section{Introduction}

Fuel cells are now recognized as a potential candidate for producing and a storing energy at different scale and thus to be relevant in many fields of the all-day life as automotive, stationary and mobile applications. The striking feature of fuel cells is the expected zero emission capability and without mechanical noise as being an electrochemical converter of hydrogen and oxygen to electricity and (warm) water, following the complete Equation 1.

$\mathrm{H}_{2}+1 / 2 \mathrm{O}_{2} \rightarrow \mathrm{H}_{2} \mathrm{O}+$ heat

A fuel cell is basically made of 2 porous electrodes (an anode and a cathode) separated by an electrolyte. This constitutes the Membrane-Electrode Assembly: MEA). Electrodes should be porous for allowing fuel and oxidant to access the catalyst in the catalyzed active zone of the electrodes (see below). The current collection is ensured by bipolar plates enclosing the 
MEA. ${ }^{[1,2]}$ Moreover the bipolar plates are designed for allowing homogeneous distribution of fuel and oxidant to the electrodes. Figure 1 summarizes this concept.

\section{Fuel (ex. $\left.\mathrm{H}_{2}\right)$}
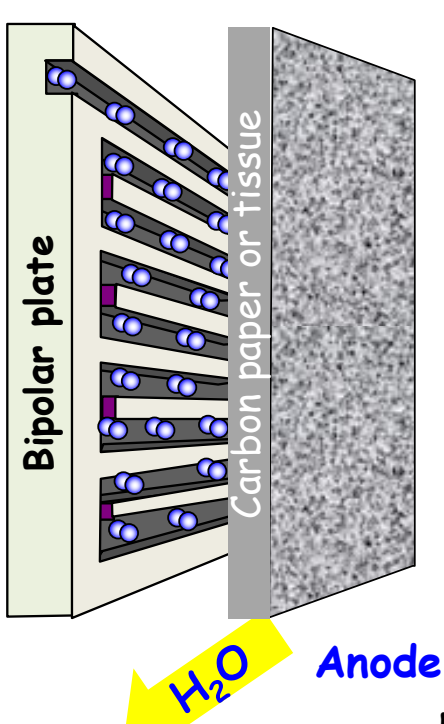

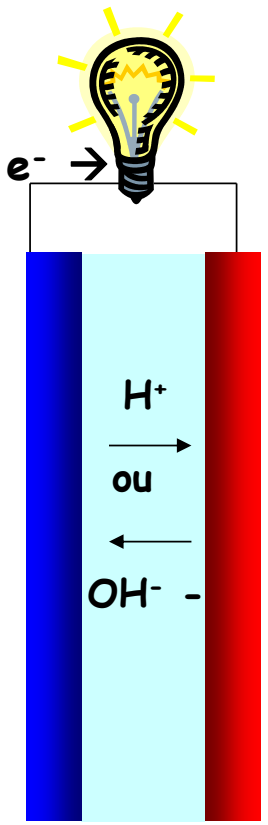

Cathode

\section{Electrolyte}
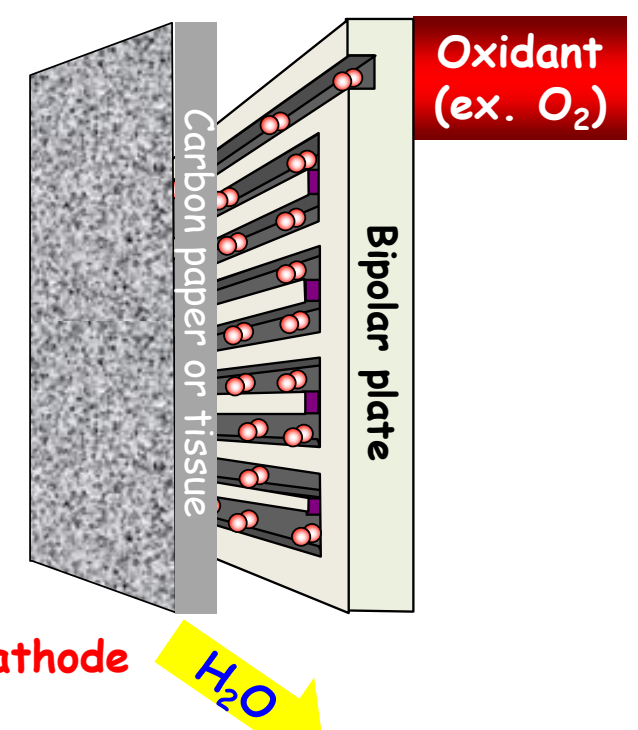

Figure 1. Schematics of a solid polymer fuel cell. Bipolar plates act both as gas distribution and current collector.

The fuel cell performance is measured either by recording potential $V(\mathrm{~V})$ or power density $P$ $\left(\mathrm{W} . \mathrm{cm}^{-2}\right)$ vs current density $j\left(\mathrm{~A} . \mathrm{cm}^{-2}\right)$. Typical maximum reached power density is around 1.0 $\mathrm{W} . \mathrm{cm}^{-2}$ at $0.7 \mathrm{~V}$, in laboratory scale fuel cell stations. Typical recorded plots are displayed on Figure 2. 


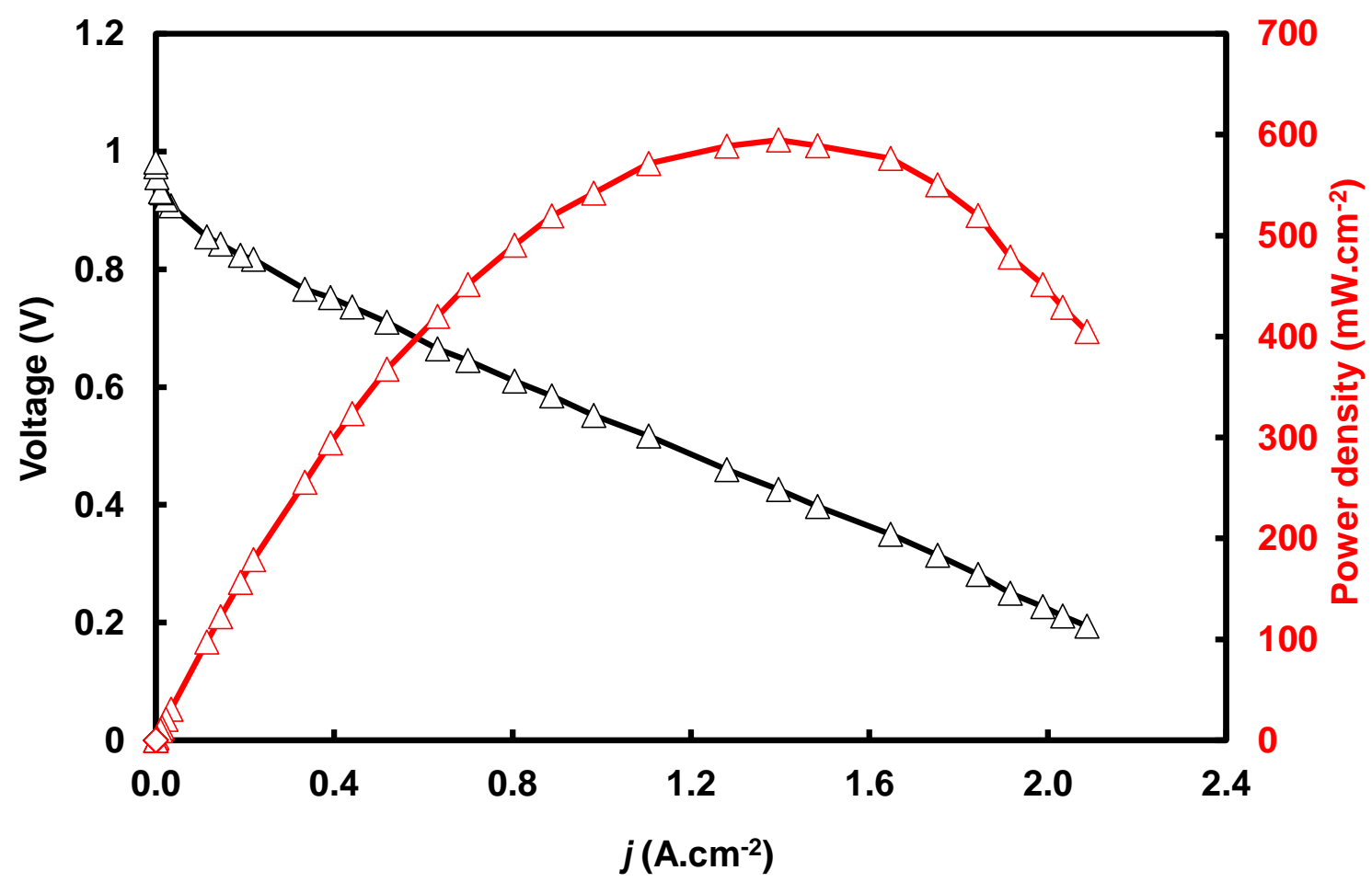

Figure 2. Typical voltage $V(j)$ and power density $P(j)$ plots. The fuel cell is loaded with 0.08 mg. $\mathrm{cm}^{-2}$ of plasma sputtered Pt at each electrodes.

In the present review, we consider the electrolyte is an ion conducting polymer membrane. The ion crossing the electrolyte can be a cation, the hydrated proton $\left(\mathrm{H}^{+}\right)$or an anion, the hydroxyl radical negative ion $\left(\mathrm{OH}^{-}\right)$. In the first case, the corresponding fuel cell is called Proton conducting membrane fuel Cell (PEMFC), while in the latter it is called Direct Alcohol Fuel Cell (DAFC). The present review will focus on electrocatalysts for PEMFC cathodes, because the main limiting step in PEMFC operation is the oxygen reduction reaction leading to water.

The electrodes are often composed of carbon tissue or paper covered by a carbon microporous layer where an activated carbon catalyzed layer (called the active layer of the electrode) is present over a depth of 10 to $50 \mu \mathrm{m} \cdot{ }^{[3-5]}$ The catalyzed layer is made of carbon particles of size from 3 to $10 \mathrm{~nm}$ surrounded by catalyst clusters of size from 0.1 to $10 \mathrm{~nm}$. Standard 
techniques make use of chemical wet methods for fabricating these active layers, i.e. impregnation-reduction method, colloidal route, carbonyl route, microemulsion and electrochemical methods. ${ }^{[6-14]}$

Besides these efficient and widely used methods, low pressure plasma methods are gaining increasing interest due to their flexibility, non-equilibrium capability allowing new paths for catalyst structure (crystalline, amorphous, core-shell, alloy, ...), composition, shape and morphology control.

Low pressure plasma processing is thus able to allow growing electrocatalyst clusters on the microporous carbon layer, ${ }^{[15-35]}$ or on the top of an existing catalyst layer for increasing outermost surface density ${ }^{[16,36]}$ or directly on the polymer electrolyte, ${ }^{[37-42]}$ to directly fabricate the carbon-electrocatalyst composite ${ }^{[22-24,26,33,39,40,43-46]}$ or to treat an already deposited (by plasma or not) electrocatalyst. ${ }^{[47-54]}$

The most efficient catalyst in PEMFC electrode is platinum and its alloys. ${ }^{[4,5,55,56]}$ supported on a microporous carbon layer. While $\mathrm{Pt}$ is a very expensive catalyst $(50 € / \mathrm{g})$, reducing its content in PEMFC electrodes is of paramount importance. There are two ways for achieving this objective: either reducing the content by alloying Pt with less expensive metals or finding alternate non-precious or metal free electrocatalysts. On the first hand, it is known that platinum-based bimetallic alloys are excellent catalysts ${ }^{[4,5,55,56]}$ for the electroreduction reaction of oxygen molecule (oxygen reduction reaction, ORR), which occurs at the cathode of PEMFC. Beyond the lowering of the platinum loading in the electrode catalytic layers, alloyed Pt-based materials lead to the improvement of the catalytic ORR activity, ${ }^{[57]}$ increase the tolerance towards poisoning species and for some authors, enhance the durability of the catalysts under fuel cell working conditions. ${ }^{[58]} \mathrm{Pt}_{\mathrm{x}} \mathrm{M}_{1-\mathrm{x}}$ bimetallic materials $(\mathrm{M}=\mathrm{Co}, \mathrm{Fe}, \mathrm{Ni}$ and $\mathrm{Cr}$ ) have been extensively studied in order to correlate their catalytic activity and their electrochemical stability towards the ORR to their composition, crystallographic and electronic structures. Current progress are dealing with Pt based trimetallic nanocatalysts, ${ }^{[59-}$ 
${ }^{62]}$ mainly for further improving catalyst stability. On the other hand, there are actually many attempts to remove the costly platinum using common metal $(\mathrm{Fe}, \mathrm{Co}, \mathrm{Cu}$, mainly bond to nitrogen $)^{[63-70]}$ or non -metal catalysts, mainly carbon based as $\mathrm{S}$ doped graphene, ${ }^{[71]} \mathrm{N}$-doped carbon nanostructures. ${ }^{[72-76]}$

The present short review will describes how low pressure plasmas are contributing to PEMFC cathode electrocatalysts design for reducing and replace cost effective platinum. The next section will be devoted to platinum electrocatalysts synthesis by low pressure plasma both directly or as a full electrode. A perspective section will concern the use of plasma for deposition and treatment of Pt alloys, non-precious and metal free electrocatalysts. A concluding section will close this review.

\section{Direct deposition of electrocatalysts on uncatalyzed electrodes}

Two plasma techniques are mainly used for this concern. First, plasma sputtering deposition of the Pt and Pt alloys. Co-sputtering, when an alloyed structure is targeted and alternate sputtering, when core-shell structures are expected, can be carried out. Second, plasma enhanced chemical vapor deposition (PECVD) of selected hydrocarbons, simultaneously or alternately with plasma sputtering is of great interest for depositing the support and the catalyst. So a carbon - Pt electrode is directly fabricated either on the uncatalyzed GDL or directly on the polymer electrolyte membrane. Another way for directly fabricating the electrode is co- or alternate sputtering of carbon and Pt based catalysts.

\subsection{Plasma sputtering}

The basic idea for using plasma sputtering is to take advantage of an atom source with controlled energy distribution lighting a porous support for acting on the electrocatalyst distribution in the porous support. So, it becomes easy to localize and control the catalyst depth profile in the electrode region in contact with the polymer electrolyte. Indeed, the 
platinum location and dispersion are essential factors determining the fuel cell performances $[18,19,77,78]$. Moreover, it is expected that the catalyst density will not be uniform throughout the porous layer due to transport diffusion mechanisms as illustrated in Figure 3.
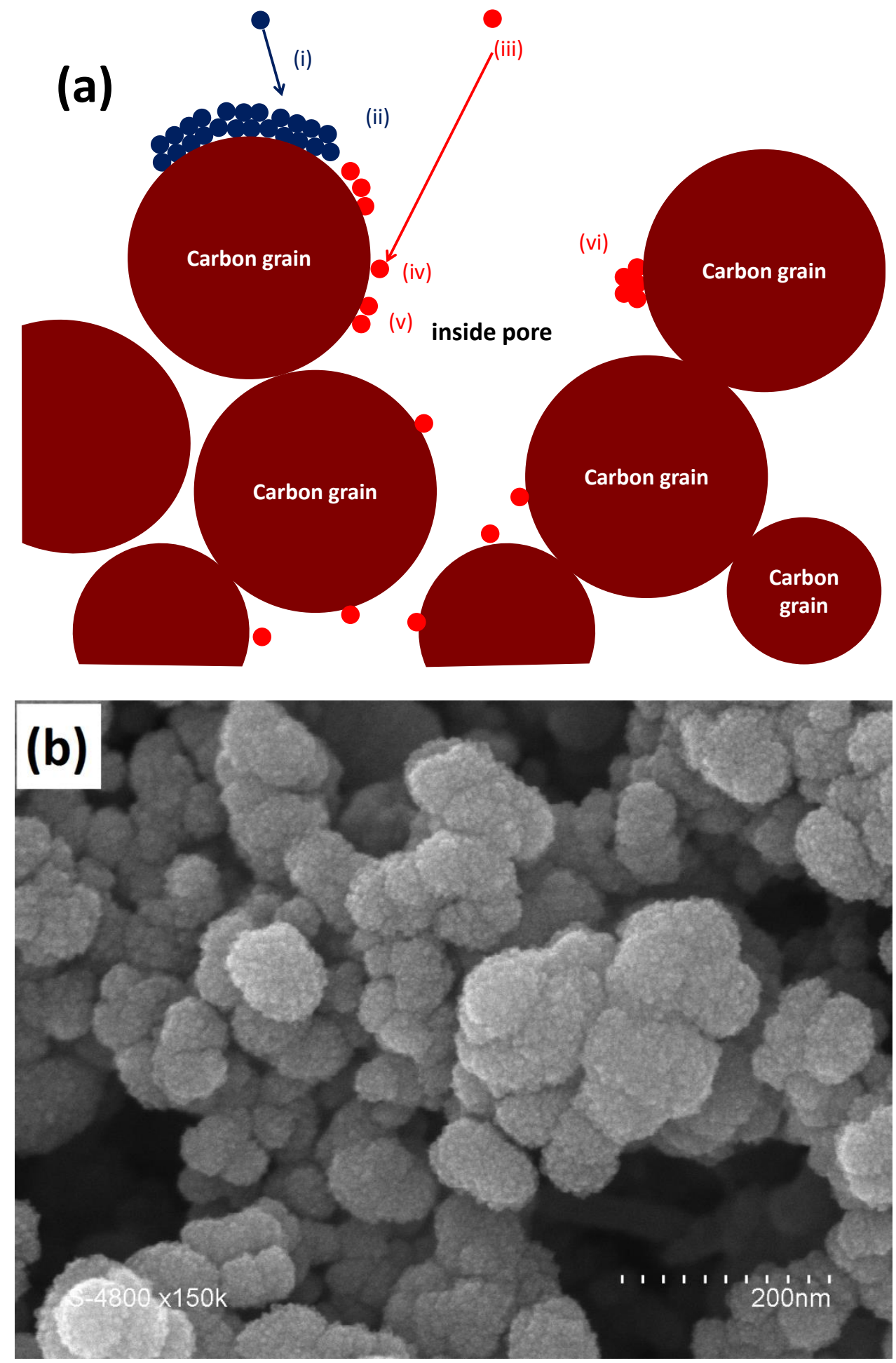

Figure 3. (a) Illustration of physical process in deposition/transport/diffusion/growth inside pores resulting from carbon grain sticking as in fuel cell electrodes. (i) catalyst atom 
adsorption and cluster growth on carbon grain top; (ii) diffusion from grain top towards pore internal wall; (iii) direct transport/adsorption on internal pore wall ; (iv) diffusion along the pore wall (v) nucleation; (vi) catalyst cluster growth inside pore. This can be apply to other kind of open pores. ${ }^{[22,23,79]}$ (b) Scanning Electron microscopy of plasma sputtered Pt deposited on an uncatalyzed electrode top surface (Courtesy D. Cot IEM Montpellier)

As demonstrated by carefully examining depth profiles of sputtered Pt catalyst, the transport/diffusion processes are not standard and depends both on support and plasma properties. ${ }^{[27]}$ Such concentration depth profiles are decreasing from the top electrodes (to be in contact with the polymer electrolyte) towards the inner part of the electrode up to a maximum depth of $2 \mu \mathrm{m}$. This concentration gradient allows to optimize the efficient use of the platinum. It is known that at high current density, catalysts close to the polymer electrolyte are more "solicited" while at low current density all the nanocatalysts present are needed. ${ }^{[77,78]}$ Moreover, Pt clusters are very well dispersed with sizes ranging from 1 to $3 \mathrm{~nm}$. Very recently, it was observed that such sputtered nanocatalysts are amorphous at very low loading $\left(10 \mu \mathrm{gPt}_{\mathrm{P} . \mathrm{cm}^{-2}}\right)$ and leading to high power density. ${ }^{[33,35]}$ Correlation between high fuel cell efficiency and catalyst amorphous structure has been independently confirmed in the case of complex Pt alloys for direct alcohol fuel cell. ${ }^{[80]}$

Dependence of the plasma sputtering parameters, plasma pressure, substrate bias, ... has also been investigated for studying the role on depth profiles. ${ }^{[18,19,27]}$ When increasing plasma pressure the kinetic energy distribution of the sputtered particle is shifted to lower energy and the mean kinetic energy is lowered too, as exemplified in Figure 4. ${ }^{[62,81]}$ 


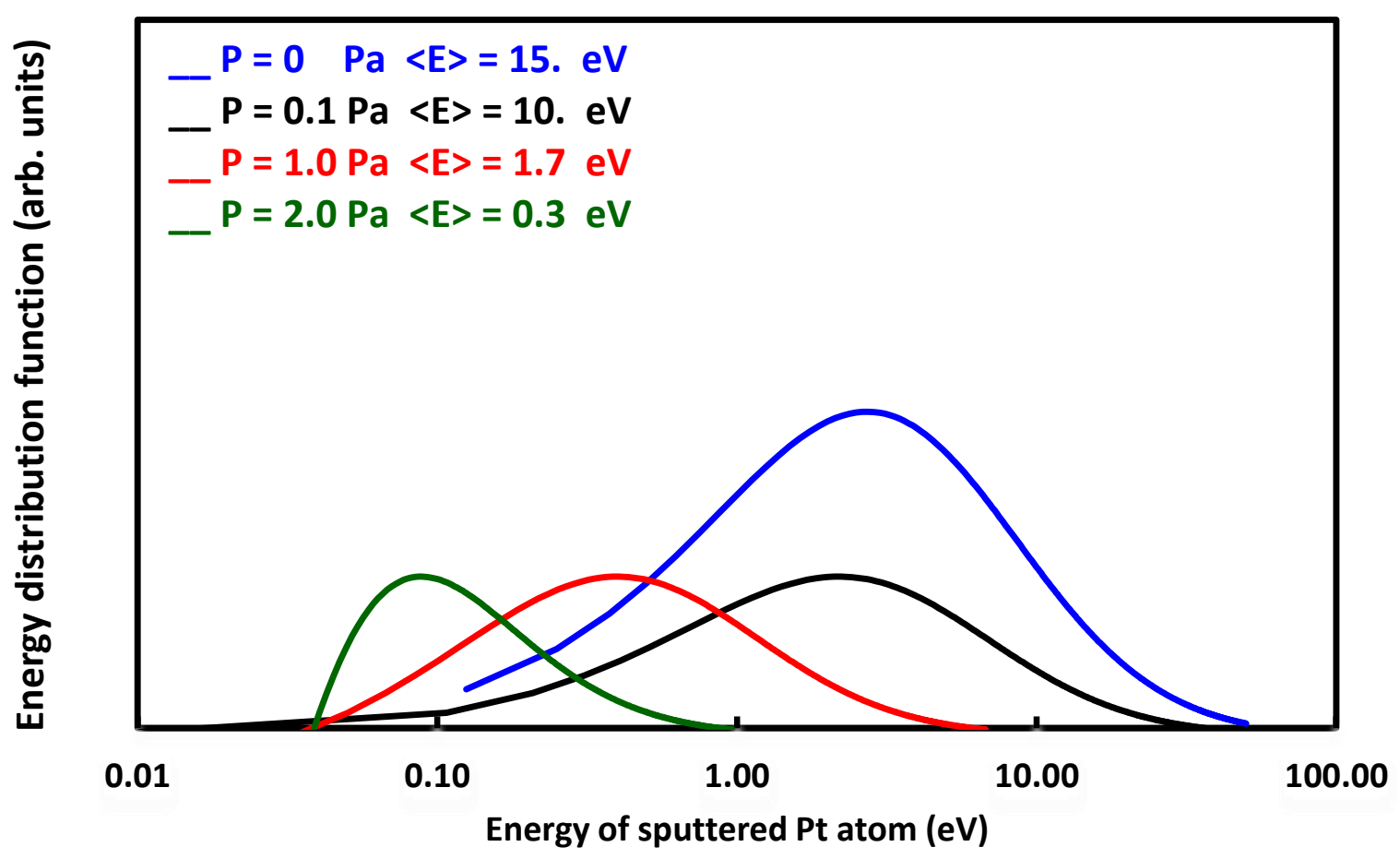

Figure 4. Example of calculated energy distribution functions of Ar plasma sputtered Pt atoms arriving at the substrate located at $10 \mathrm{~cm}$ from the sputtered target biased at $300 \mathrm{~V}$. Plots are given for different Ar pressures $P$ (log scale for the abscissae). $\langle E\rangle$ is designated the mean kinetic energy of the corresponding energy distribution. Reprinted from Ref. 62.

In Figure 5 are plotted the Pt depth profiles vs plasma pressure and substrate bias. ${ }^{[18,19,82]}$
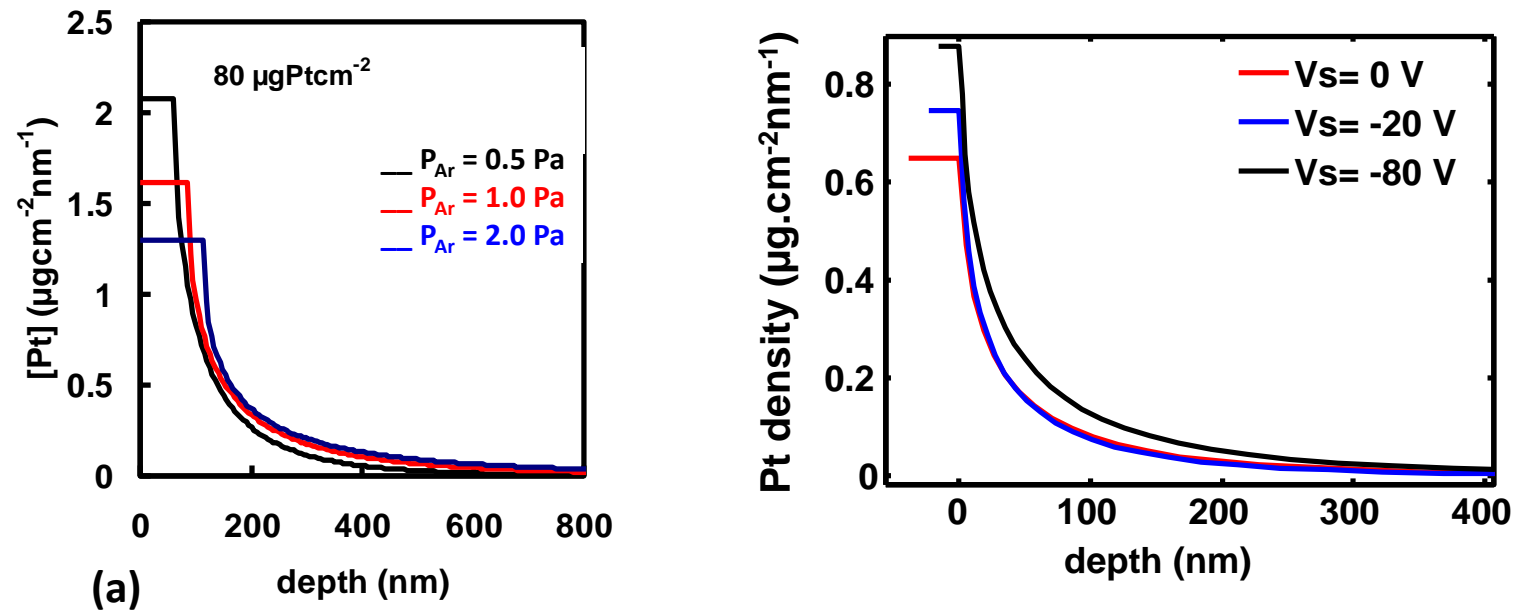

Figure 5. Examples of Pt concentration depth profiles vs (a) argon plasma pressure in the sputtering chamber and (b) porous carbon uncatalyzed electrode bias. Reprinted from Ref. 82 
Increasing the plasma pressure results in lowering the catalyst density and thickness of the catalyst located on the top of the porous carbon substrate. The general shape of the concentration profile inside the porous layer does not change. ${ }^{[27]}$ When increasing substrate bias voltage, i.e. increasing the plasma ion (mainly Argon ion in the considered experiments $^{[18,19,82]}$ ) energy, simultaneously to the deposition on the substrate, the shape of the catalyst concentration profile is slightly modified: above a threshold, which depends on the substrate material and structure, the impinging ion transfers enough energy for increasing mobility of catalyst atom towards the in-depth of the porous substrate. But when increasing deposition time, the pore entrances of the electrode start to be filled and thus reactants cannot access the polymer electrolyte, and protons cannot cross the polymer electrolyte. So using sputtering deposition requires low catalyst loading. Nevertheless, this constraint leads to Pt low content and fuel cell performance are high enough, indicating a more efficient use of a lesser catalyst content. In this case high mass power density up to $20 \mathrm{~kW} \cdot \mathrm{g}_{\mathrm{Pt}}{ }^{-1},{ }^{[26]}$ are reached which are among the highest to date. ${ }^{[56]}$

\subsection{Direct deposition of the full active layer: catalyst + support}

A relevant goal is to be able to fabricate the active layer (part of the electrode which is catalyzed) in a single step, both for economic reason (based upon single fabrication machine) and on-demand electrode and MEA design capability. Contrary to the previous section, there is not so much work on the growth of the catalyzed electrode itself. This section will focus on

plasma co-sputtering ${ }^{[39,40,83,84]}$ of and combination of PECVD and sputtering ${ }^{[43-46]}$ of support and catalyst for fabricating the active layer. This active layer should be enough electron conducting i.e. close to graphite conduction level. The open porosity of the active layer should high enough, at least $20 \%$ up to $60 \%$ maximum for allowing efficient gas transport to nanocatalysts. 
Carbon and Pt co-sputtering has been carried out for testing the capability of the method for obtaining the correct structure of the active layer ${ }^{[39,40]}$. Flexibility of the co-sputtering technique allows to deposit simultaneously carbon and platinum or alternate carbon and $\mathrm{Pt}$ deposition in a way to design a Pt concentration profile. In all cases, the active layer is made of Pt-C columns leading to a porosity ranging from 20 to 65\%, as requested (see Figure 6 and

\section{Figure 7).}

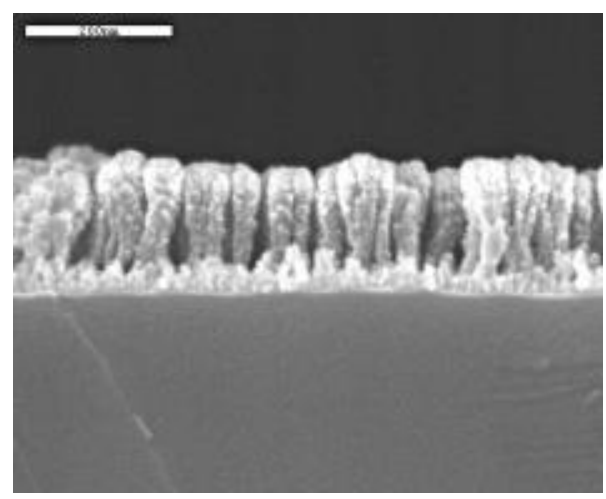

Figure 6. Scanning Electron Microscopy of a typical co-sputtered Pt-C active layer. Reprinted from Ref. 39. 


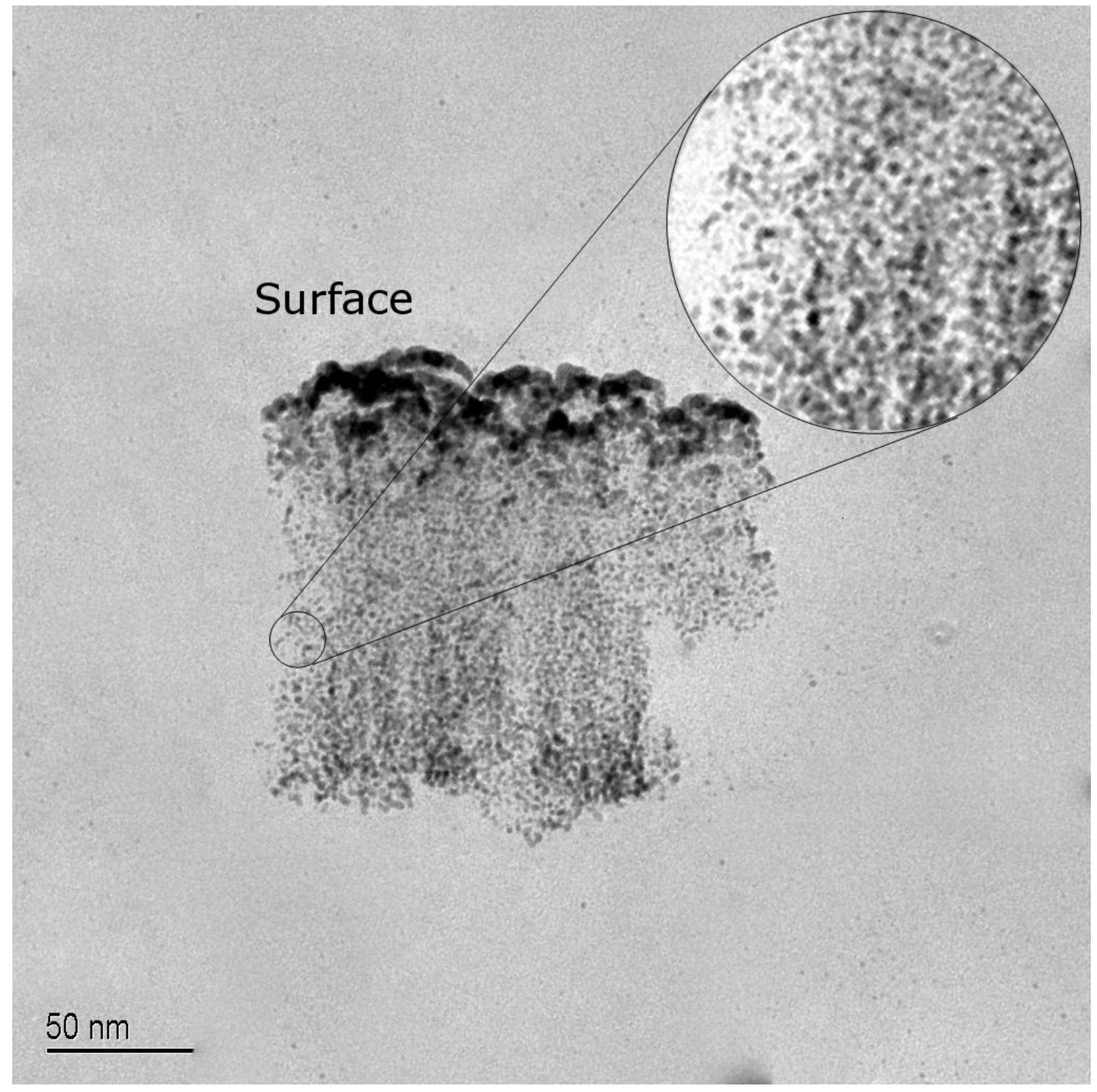

Figure 7. Transmission Electron Microscopy of Pt-C columns showing small Pt clusters (dark areas). Reprinted from Ref. 40.

Examination of the Open Circuit Voltage of such PtC electrodes deposited on a Nafion ${ }^{\circledR}$ polymer electrolyte shows better performances than commercial electrodes for alternate deposition of Pt and C. This has been correlated to the low Pt cluster size $(2 \mathrm{~nm})$ and to the fact that Pt is always decorating carbon columns ${ }^{[83]}$, even when $\mathrm{Pt}$ is co-sputtered simultaneously with $\mathrm{C}$, as displayed in Figure 8. 


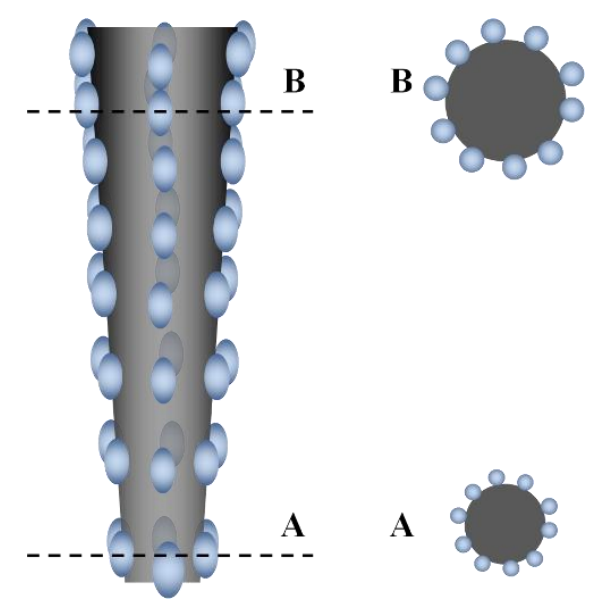

Figure 8. Schematics of the Pt localization along carbon column and Pt cluster size evolution. Adapted from Ref. 83

In this case, all Pt atoms are accessible to fuel cell electrochemical reactions.

A more versatile way is provided by combining carbon precursor PECVD and Pt plasma sputtering for direct deposition. The flexibility of the method lies in the different possible carbon precursor: $\mathrm{C}_{2} \mathrm{H}_{4}, \mathrm{C}_{3} \mathrm{~F}_{6} \ldots$ and in the possible control of the gas phase reaction leading to the optimized carbonaceous support of the simultaneously sputtered catalyst. Fluorinated plasma is an important choice due to the need of making the electrode hydrophobic for water management in the fuel cell, which was not addressed in previous $\mathrm{Pt}-\mathrm{C}$ co-sputtering technique. Classical electrodes include Teflon grains for this purpose. The setup displayed in Figure 9 allows to simultaneously PECVD and sputtering Pt target located on the powered electrodes. Improvement of the system is achieved by pulsing the gas flux. 


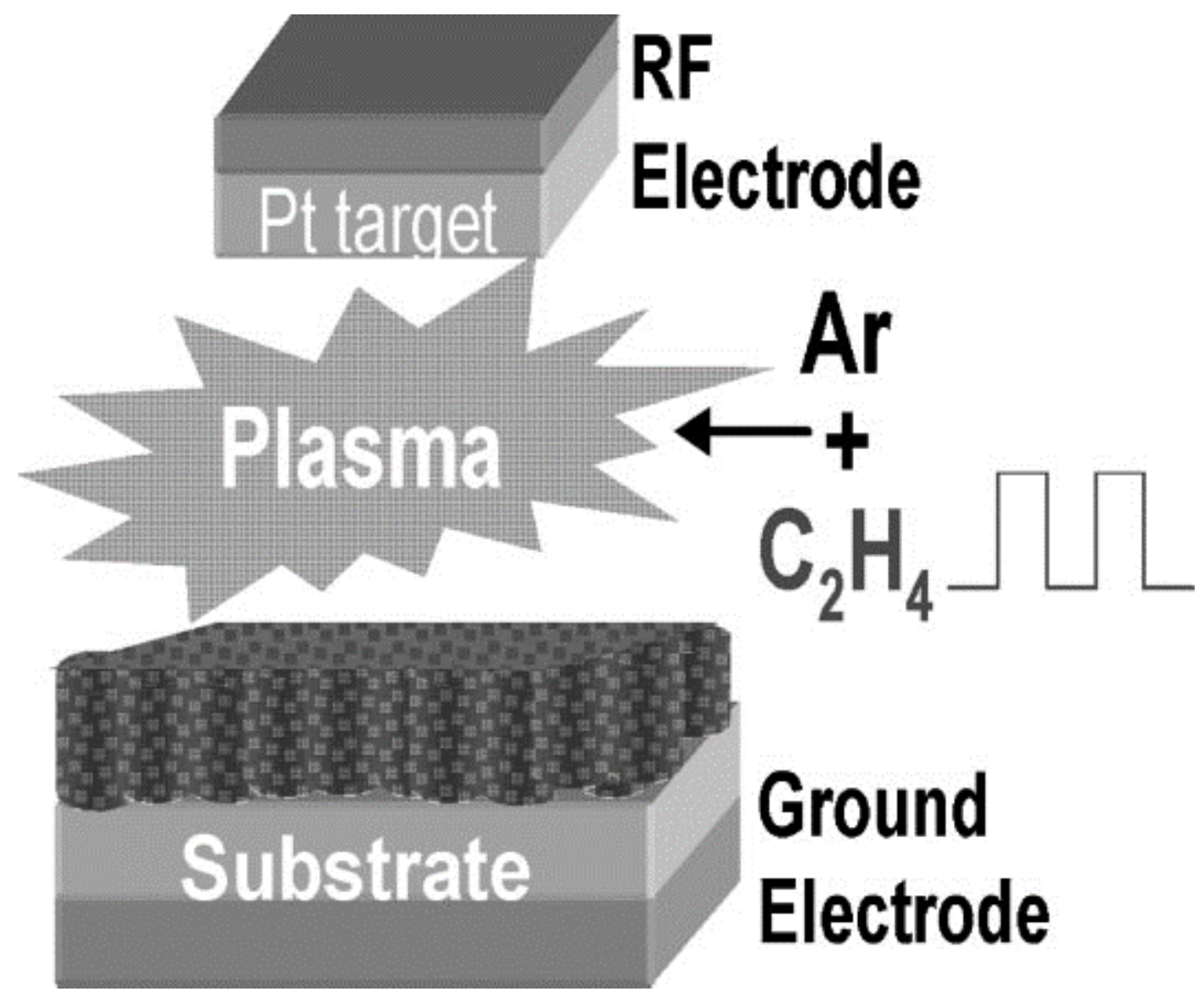

Figure 9. Schematics of the Pt-C nanocomposit plasma deposition combining PECVD and sputtering. Reprinted from Ref. 45

Figure 10 shows that film morphology is characterized by columnar structures of variable diameter and orientation depending on the deposition conditions. 

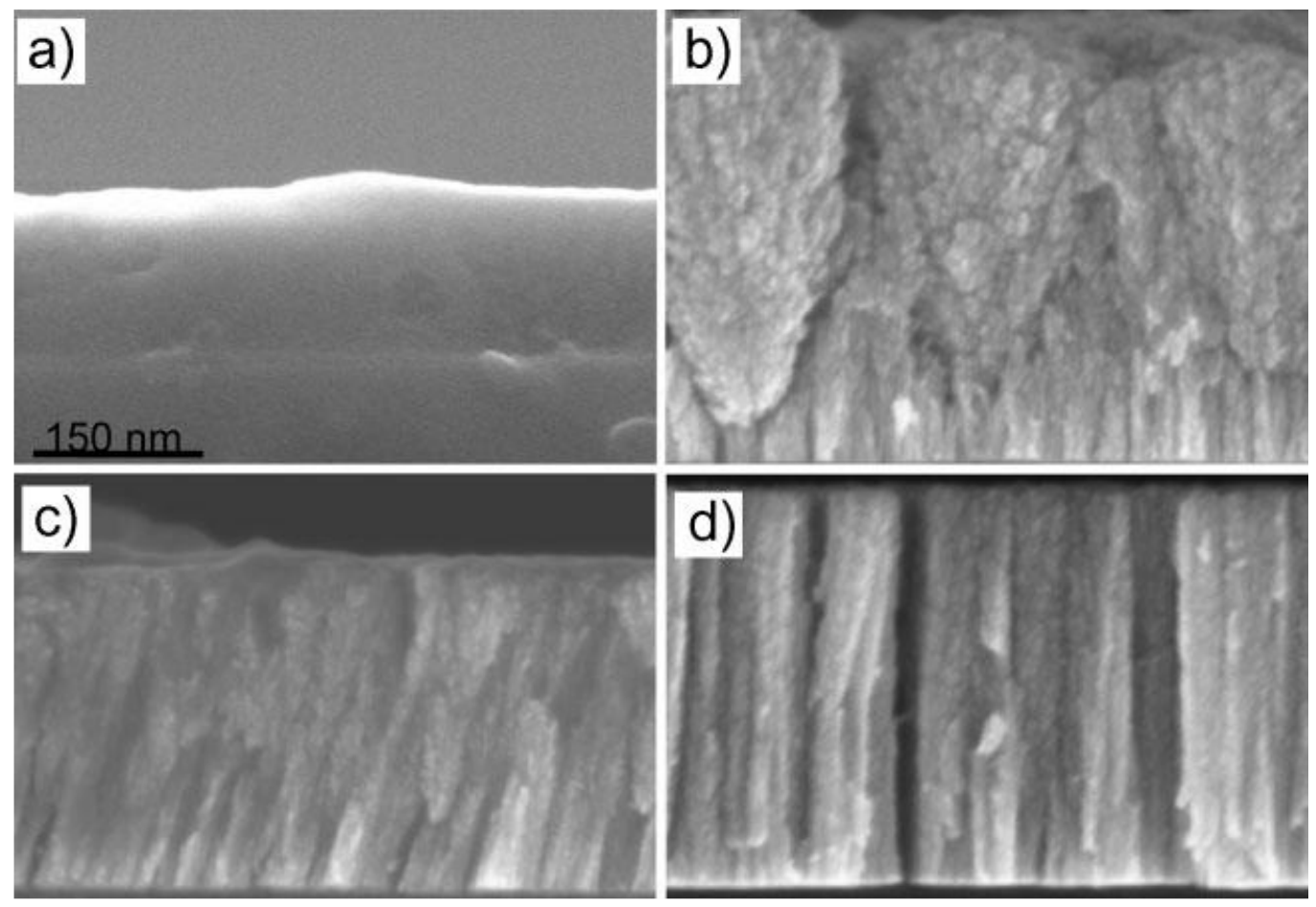

Figure 10. Scanning Electron Microscopy images of hydrocarbon films deposited at 0.8 sccm C2H4 and a) $100 \mathrm{~W}(0 \% \mathrm{Pt})$; b) 350W (42\% Pt); c) 600W (60\% Pt); d) 800W (80\% Pt). reprinted from Ref. 43.

Pt clusters are embedded in the hydrocarbon columns. But it is shown that this does not prevent fuel cell efficiency. This is due to the porous nature of the columns, leading to Pt catalytic efficiency. Figure 11 shows deposited Pt nanocatalysts have sizes around $5 \mathrm{~nm}$ and are well crystallized.
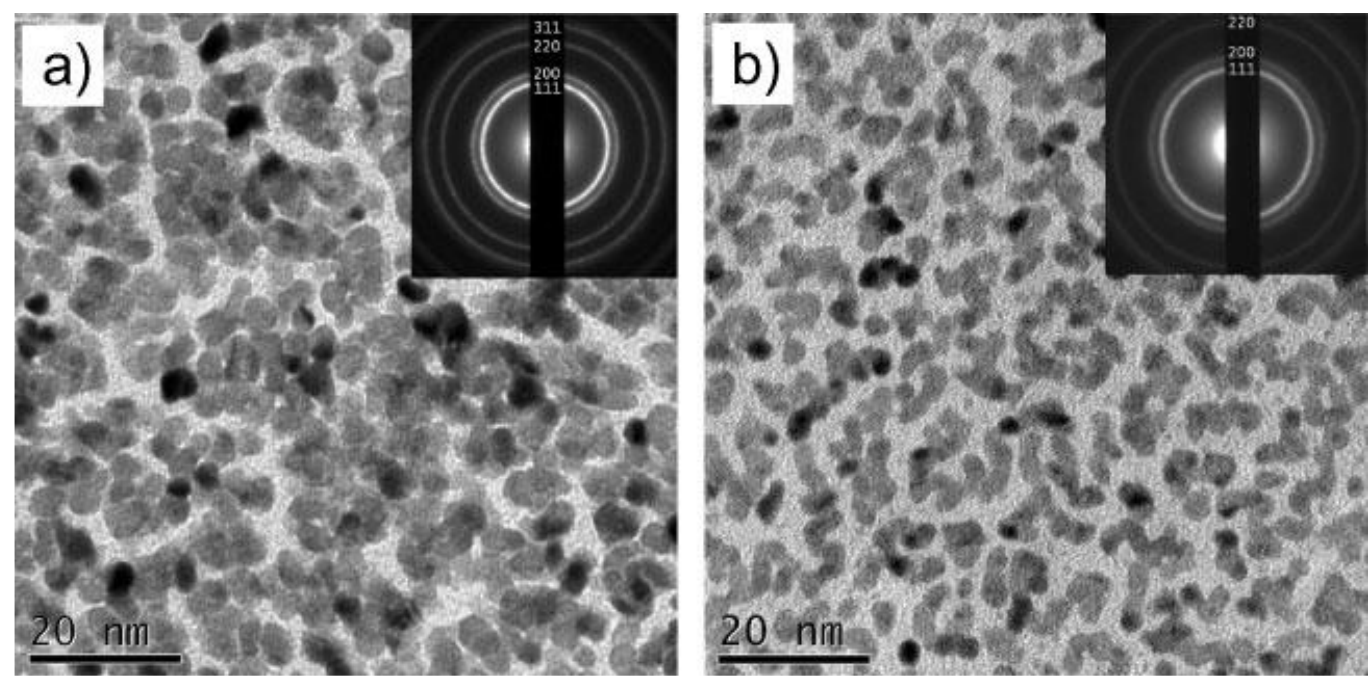
Figure 11. Transmission electron Microscopy pictures and Selected Area Diffraction (inset) of film containing a) $60 \%$ of Pt and b) $1 \%$ of Pt. Reprinted from ref. 43.

When operating with fluorocarbon gas $\mathrm{C}_{3} \mathrm{~F}_{6}$, Figure 12 shows that the morphology of the film is more homogeneous than with $\mathrm{C}_{2} \mathrm{H}_{4}$ precursor, and platinum is well dispersed and is observed to be in metallic form, and as nanocrystalline clusters of variable size (less than 10 $\mathrm{nm})$ depending on the Pt content.
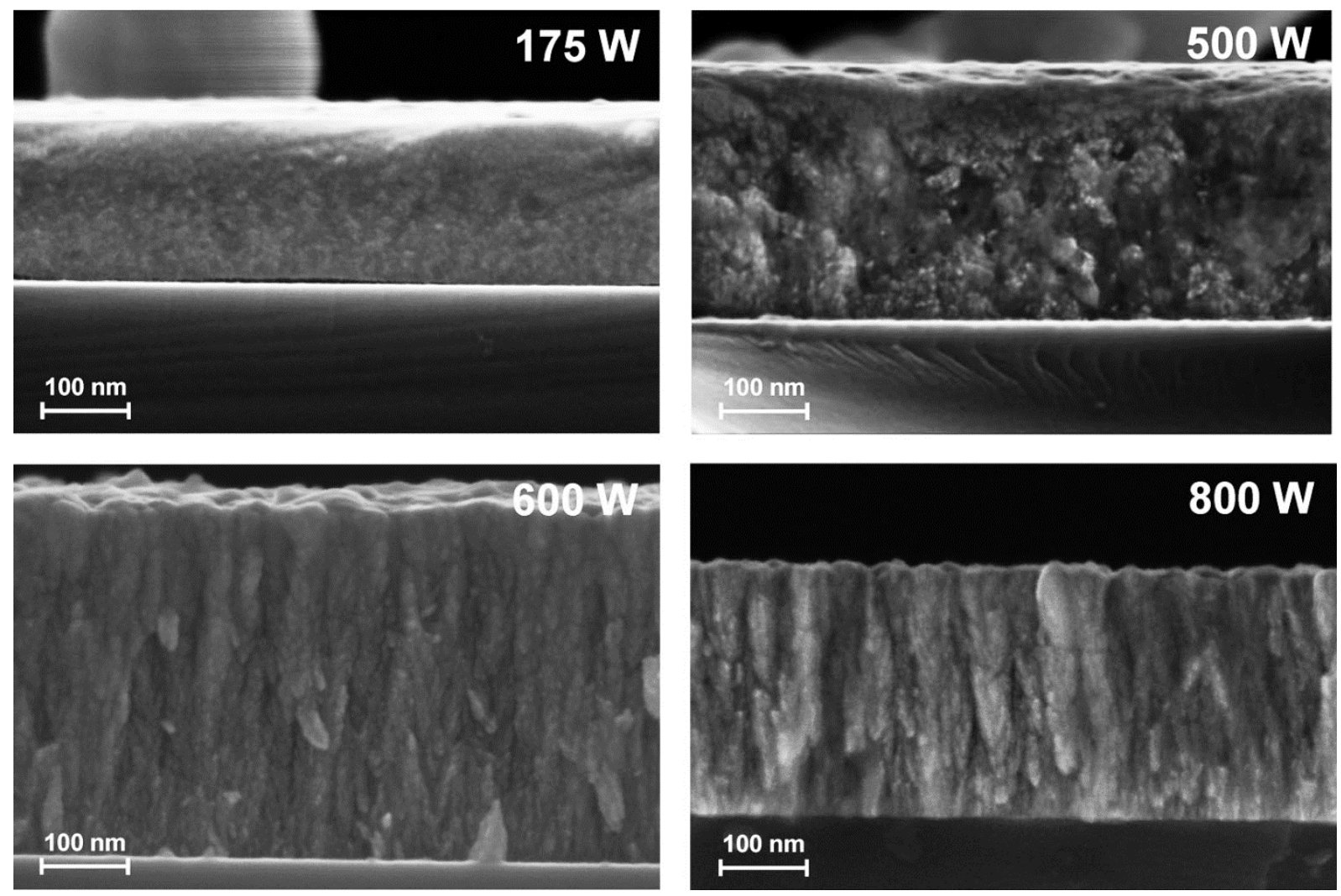

Figure 12. Scanning Electron Microscopy images of Pt-fluorocarbon films deposited at different Radio Frequency powers. Reprinted from ref. 46.

A key point of these two deposition methods is the very low possible thickness of the active layer, making it suitable for micro fuel cell design, ${ }^{[85,86]}$, the PECVD method being relevant for also depositing the polymer electrolyte. ${ }^{[85,86]}$

\section{Perspectives}




\subsection{Multi-metallic catalysts}

The rapid evolution of the field of electrocatalysis requires that the use of plasmas for fabricating electrocatalysts, especially for fuel cells, should increase too. Indeed, key point is bi and tri-metallic catalyst design leading to the reduction of the Pt content. In this case, simultaneous or alternate sputtering or co-sputtering is able to easily give various catalyst structures: alloy, core-shell and mixed alloy/core-shell. As an illustration, recent DFT calculations have shown that binary PtPd thin films, in which Pt comprises the skin and Pd is restricted to the subsurface layer(s) are the best catalysts for oxygen reduction ${ }^{[87]}$, in agreement with experiments ${ }^{[29]}$ for which the highest mass power density to date was reached $\left(250 \mathrm{~kW} \cdot \mathrm{gPt}^{-1}\right) \cdot{ }^{[29,56]}$ Moreover, the addition of a small, amount of Au can be beneficial for the efficiency of the ternary catalyst $\mathrm{PtPdAu}$ (especially, $\mathrm{Pt}_{2} \mathrm{Au} / \mathrm{Pd}_{3} / \mathrm{Pd}$ and $\mathrm{PtAu}_{2} / \mathrm{Pd}_{3} / \mathrm{Pd}$ ) by preventing the dissolution of under-coordinated Pt atoms, and perhaps even enhancing the activity, making the ternary PtPdAu systems interesting for the ORR in PEMFCs. ${ }^{[87]}$ Experiments ${ }^{[88]}$ on $\mathrm{Pt}_{50} \mathrm{Pd}_{25} \mathrm{Au}_{25}$ and $\mathrm{Pt}_{70} \mathrm{Pd}_{15} \mathrm{Au}_{15}$ confirms the interest for ORR, but it is noticed that $\mathrm{Au}$ is segregating to the surface during electrochemical ageing, as predicted by DFT calculations too. ${ }^{[87]}$ Moreover, Molecular dynamics simulations including initial conditions matching sputtering experiment show that sequential sputtering is required for obtaining DFT predicted catalyst structure. ${ }^{[62]}$ If only co-sputtering of the three metals is chosen, Au atoms are segregating towards surface of the ternary PtPdAu cluster as shown in Figure 13. 


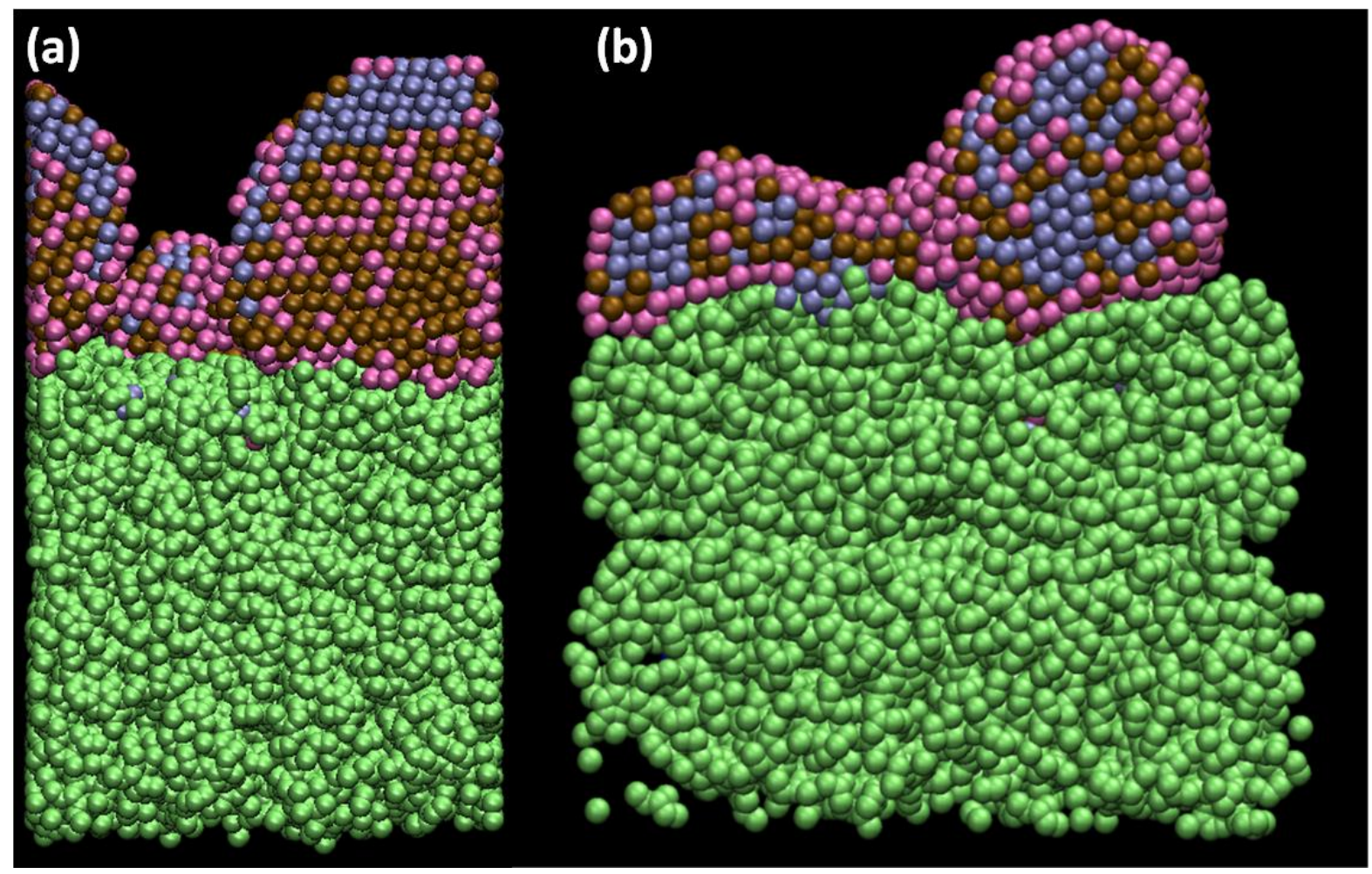

Figure 13. Molecular dynamics simulations matching plasma sputtering deposition of ternary catalyst PtPdAu. Cross-sectional view of the deposited catalyst clusters. (a) PdAu core cosputtering followed by Pt sputtering (b) simultaneous co-sputtering of Pt, Pd, Au on model porous carbon. $\bullet C, \bullet P d, \bullet P t, \bullet A u$. Adapted from Ref. 62

\subsection{Nonprecious and metal free catalysts}

Non-precious metal and metal free catalysts for PEMFC ${ }^{[89]}$ is an active field of research and plasma techniques certainly have the opportunity to bring novelty and original results.

Non precious catalysts in the form of non-precious metal (Fe, $\mathrm{Ni}, \mathrm{Mo}, \mathrm{Cu}$ ) bounded to four nitrogen atoms as in metal porphyrine or phtalocyanine, are well suited for benefiting from plasma techniques. As example, Figure 14 display the structure of a metal tetramethylporphyrin, Me TMPP, where Me stand for $\mathrm{Co}, \mathrm{Fe}, \mathrm{Cu}, \ldots$ 


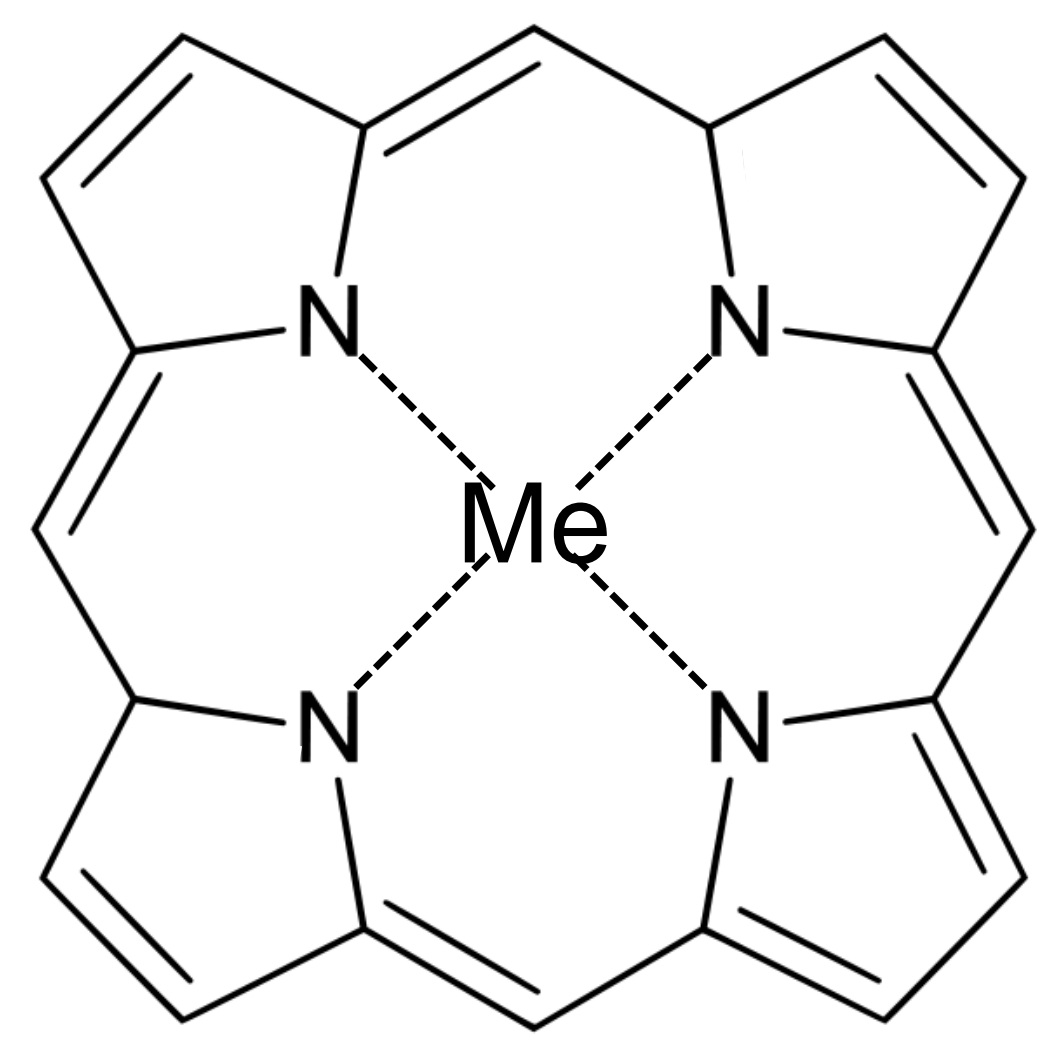

Figure 13: Structure of a generic Metal Tetra-Methyl Porphyrin. Me stands for a metal atom like $\mathrm{Co}, \mathrm{Cu}, \mathrm{Fe}$.

Metal porphyrine and phtalocyanine molecules can be efficient non-precious catalyst ${ }^{[63-66]}$, but they require post deposition heat treatment for only having metal-nitrogen bonds identified as the active catalytic sites. Pioneering work of Easton et al ${ }^{[69,70]}$ using magnetron combinatorial deposition allowed to sweep a large range of composition among ( $\mathrm{Fe}, \mathrm{Co}) \mathrm{C}-\mathrm{N}$ system. Post deposition heat treatments favoured the catalyst activity and durability up to 1000 hours. Highest reported fuel cell power densities were in the range $400 \mathrm{mWcm}^{-2}$, using such techniques.

Preliminary plasma treatments were carried out for replacing heat treatments. ${ }^{[47-54]}$ Inductive (ICP) or Dielectric Barrier Discharge (DBD) plasma plasmas were built and a vibrating substrate holder allowed to uniformly treat all the catalysed powder. Main result was the improvement of the catalyst activity and reducing of the catalyst material losses compared to heat treatment. 
Concerning metal-free catalyst, work focusses on nitrogen doped C nanostructures. ${ }^{\text {[72-76] }}$ Curiously, as functionalization is an attractive field for plasma chemistry, N-doping of carbon using plasma has not so much attracted attention. Nevertheless plasma functionalization using nitrogen precursor is very well understood now and might be of interest for fuel cell development without precious or non-precious metal catalyst. ${ }^{[75,90-96]}$ Moreover, some of these work on metal free electrodes can be directly adapted for preparing electrodes for lithium and sodium batteries. ${ }^{[97-99]}$ In this context, parametric studies correlating plasma properties to catalytic performance in fuel cells are highly desirable for understanding the gain in using plasmas and finding the way for significantly improve metal-free PEMFC electrode performances.

As a further perspective, the use of cold atmospheric plasma can be promising techniques for fabricating PEMFC electrodes, ${ }^{[48,53,93,100,101]}$ both for catalyst and electrode deposition or treatment.

\section{Conclusion}

This short review has emphasized on the use of plasmas for studying and improving electrocatalysts required for fuel cell operation, especially PEMFC. It is shown that plasmas are very versatile tools allowing many combinations of nanocatalyst composition, structure, morphology, leading to improved catalytic properties and fuel cell performances. The development of new type of electrocatalysts will leads to new plasma improvement dedicated to optimize the design in view of improving fuel cell performances, both activity and durability.

Acknowledgements. I would like to warmly thanks all my colleagues at GREMI who contributing to the works in the field: Anne-Lise Thomann, Amael Caillard, Johannes Berndt, Yves Tessier, Thomas Lecas, Stéphane Cuynet, Mathieu Mougenot, Marjorie Cavarroc, 
Hervé Rabat, Raphaël Escalier, and the colleagues who collaborate with us: Christine Charles, Rod Boswell, Erik Neyts, Anemie Bogaerts, Christophe Coutanceau, Steve Baranton, Claude Lamy, Gerald Pourcelly, Jean Durand, Stéphanie Roualdès, Pierrick Buvat, Janick Bigarré, Rémy Vincent, Sébastien Rosini, Luis Colménares, Tejs Vegge, Doetze Sikkema. CNRS through the successive Fuel Cell GdRs and PIE is gratefully acknowledged for constant support of "plasma for fuel cells" activities. Part of the presented work is supported by European Commission under the FP7 Fuel Cells and Hydrogen Joint Technology Initiative grant agreement FP7-2012-JTI-FCH-325327 for the SMARTCat project.

Received: ((will be filled in by the editorial staff)); Revised: ((will be filled in by the editorial staff)); Published online: ((please add journal code and manuscript number, e.g., DOI: 10.1002/ppap.201100001))

Keywords: catalyst, cold plasma, deposition, plasma-enhanced chemical vapor deposition, sputtering

[1] R. P. O'Hayre, S. W. Cha, W. Colella, F. B. Prinz, Fuel cell fundamentals, Wiley, Hoboken, NJ, USA 2006

[2] Y. Wang, K. S. Chen, J. Mishler, S. C. Cho, X. Cordobes Adroher, Applied Energy 2011, 88,981

[3] S. Litster, G. McLean, PEM fuel cell electrodes, J. Power Sources 2004, 130, 61.

[4] M. T. Koper, Fuel Cell Catalysis, Wiley, Hoboken NJ 2009.

[5] J. Zhang, PEM Fuel Cell Electrocatalysts and catalysts Layers, Springer, London, 2008

[6] C. Coutanceau, S. Baranton, T. W. Napporn, in The Delivery of Nanoparticles (Ed.: A. Hashim), InTech Publisher, Rijeka, Croatia 2011, Ch. 19 pp. 403-430 
[7] R. Sellin, C. Grolleau, C. Coutanceau, J.-M. Leger, S. Arrii-Clacens, S. Pronier, J.-M. Clacens, J. Phys. Chem. C 2009, 113, 21735.

[8] L. Dubau, F. Hahn, C. Coutanceau, J.-M. Léger, C. Lamy, J. Electroanal. Chem. 2003, $554-555,407$.

[9] S. Brimaud, C. Coutanceau, E. Garnier, J.-M. Léger, F. Gérard, S. Pronier, M. Leoni, J. Electroanal. Chem. 2007, 602, 226.

[10] C. Grolleau, C. Coutanceau, F. Pierre, J.-M. Léger, J. Power Sources 2010, 195, 1569.

[11] E. Lebègue, S. Baranton, C. Coutanceau, J. Power Sources 2011, 196, 920.

[12] H. Yang, C. Coutanceau, J.-M. Léger, N. Alonso-Vante, C. Lamy, J. Electroanal. Chem. 2005, 576, 305.

[13] F. Vigier, C. Coutanceau, A. Perrard, E. M. Belgsir, C. Lamy, J. Appl. Electrochem. 2004, 34, 439.

[14] C. Coutanceau, A. Rakotondrainibe, A. Lima, E. Garnier, S. Pronier, J.-M. Léger, C. Lamy, J. Appl. Electrochem. 2004, 34, 61.

[15] A. T. Haug, R.E. White, J. W. Weidner, W. Huang, S. Shi, T. stoner, N. Rana, J. Electrochem. Soc. 2002, 149, 1280

[16] S. Hirano, J. Kim, S. Srinivasan, Electrochimica Acta 1997, 42, 1587

[17] P. Andreazza, C. Andreazza-Vignolle, J. P. Rozenbaum, A.-L. Thomann, P. Brault, Surf. Coat. Technol. 2002, 151-152, 122

[18] P. Brault, A. Caillard, A. L. Thomann, J. Mathias, C. Charles, R. W. Boswell, S. Escribano, J. Durand, T. Sauvage, J. Phys. D 2004, 37, 3419

[19] A. Caillard, P. Brault, J. Mathias, C. Charles, R. Boswell, T. Sauvage, Surf. Coatings Technol. 2005, 200, 391

[20] P. Brault, S. Roualdès, A. Caillard, A.L. Thomann, J. Mathias, J. Durand, Ch. Coutanceau, J.M. Léger, C. Charles, Rod Boswell, Eur. Phys. J. Applied Phys. 2006, 34, 151 
[21] A. Caillard, Ch. Coutanceau, P. Brault, J. Mathias, J.-M. Léger, J. Power Sources 2006, 162, 66

[22] A. Caillard, C. Charles, R. Boswell , P. Brault, Ch. Coutanceau, Appl. Phys. Lett. 2007, 90, 223119

[23] A. Caillard, C. Charles, R. Boswell, P. Brault, Nanotechnology 2007, 18, 305603

[24] A. Caillard, C. Charles, R. Boswell and P. Brault, J. Phys. D 2008, 48, 185307

[25] A. Caillard, C. Charles, R. Boswell, A. Meige and P. Brault, Plasma Sources Sci. Technol. 2008, 17, 035028

[26] M. Cavarroc, A. Ennadjaoui, M. Mougenot, P. Brault, R. Escalier, Y. Tessier, J. Durand, S. Roualdès, T. Sauvage, C. Coutanceau, Electrochemistry Communications 2009, 11,859

[27] P. Brault, Ch. Josserand, J.-M. Bauchire, A. Caillard, Ch. Charles, R. W. Boswell, Phys. Rev. Lett. 2009, 102, 045901

[28] P. Brault, Surf. Coat. Technol. 2011, 205, S15

[29] M. Mougenot, A. Caillard, P. Brault, S. Baranton, C. Coutanceau, International Journal of Hydrogen Energy 2011, 36, 8429

[30] C. Lamy, D. J. Jones, C. Coutanceau, P. Brault, S. Martemianov, Y. Bultel, Electrochimica Acta 2011, 56, 10406

[31] M. Mougenot, A. Caillard, M. Simoes, S. Baranton, C. Coutanceau, P. Brault, Applied Catalysis B: Environmental 2011, 107, 372

[32] P. Brault, A. Caillard, C. Charles, R. Boswell, D. B. Graves, Appl. Surf. Sci. 2012, 263,352

[33] P. Brault, A. Caillard, S. Baranton, M. Mougenot, S. Cuynet, C. Coutanceau, ChemSusChem 2013, 6, 1168

[34] S. Cuynet, A. Caillard, Th. Lecas, J. Bigarre, P. Buvat, P. Brault, J. Phys. D 2014, 47, 272001 
[35] L. Xie, P. Brault, C. Coutanceau, A. Caillard, J. Berndt, E. Neyts, Appl. Cat. B 2015,

62,21

[36] S. Mukerjee, S. Srinivasan; A. Appleby, Electrochimica Acta 1993, 38, 1661

[37] S. Y. Cha, W. M. Lee., J. Electrochem. Soc. 1999, 146, 4055

[38] R. O’Hayre, S.-J. Lee, S.-W. Cha, F.B. Prinz, J. Power Sources 2002, 109483

[39] H. Rabat, P. Brault, Fuel Cells 2008, 8, 81

[40] H. Rabat, C. Andreazza, P. Brault, A. Caillard, F. Béguin, C. Charles, R. Boswell, Carbon 2009, 47, 209

[41] C. Coutanceau, P. Brault, A. Caillard, M. Mougenot, S. Baranton, A. Ennadjaoui, M. Cavarroc, ECS Transactions 2011, 41, 1151

[42] S. Cuynet, A. Caillard, S. Kaya-Boussougou, T. Lecas, N. Semmar, J. Bigarré, P. Buvat, P. Brault, J. Power Sources 2015, 298, 299

[43] E. Dilonardo, A. Milella, F. Palumbo, G. Capitani, R. d'Agostino, F. Fracassi, Plasma Process. Polym. 2010, 7, 51.

[44] E. Dilonardo, A. Milella, F. Palumbo, J. Thery, S. Martin, G. Barucca, P. Mengucci, R. d'Agostino, F. Fracassi, J. Mater. Chem 2010, 20, 10224

[45] E. Dilonardo, A. Milella, P. Cosma, R. d'Agostino, Fabio Palumbo, Plasma Process. Polym. 2011, 8, 452-458

[46] A. Milella, F. Palumbo, E. Dilonardo, G. Barucca, P. Cosma, F. Fracassi, Plasma Process. Polym. 2014, 11, 10682

[47] I. Herrmann, V. Brüser, S. Fiechter, H. Kersten, and P. Bogdanoff, J. Electrochem. Soc. 2005, 152, A2179

[48] N.A. Savastenko, V. Brüser, M. Brüser, K. Anklam, S. Kutschera, H. Steffen, A. Schmuhl, J. Power Sources 2007, 165, 24.

[49] V. Brüser, N. Savastenko, A. Schmuhl, H. Junge, I. Herrmann, P. Bogdanoff, K. Schröder, Plasma Process. Polym. 2007, 4, S94-S98 
[50] F. Harnisch, N.A. Savastenko, F. Zhao, H. Steffen, V. Brüser, U. Schröder, J. Power Sources 2009, 193, 86.

[51] I. Herrmann, U. I. Kramm, S. Fiechter, V. Brüser, H. Kersten, P. Bogdanoff, Plasma Process. Polym. 2010, 7, 515

[52] S. Wirth, Falk Harnisch, A. Quade, M. Brüser, V. Brüser, U. Schröder, N. A.

Savastenko, Plasma Process. Polym. 2011, 8, 914

[53] N. A. Savastenko, V. Brüser, Applied Surface Science 2011, 2573480

[54] N. A. Savastenko, K. Anklam, A. Quade, M. Brüser, A. Schmuhl, V. Brüser, Energy Environ. Sci. 2011, 4, 3461

[55] A. Chen, P. Holt-Hindle, Chem. Rev. 2010, 110, 3767.

[56] A. Brouzgou, S.Q. Song, P. Tsiakaras, Applied Catalysis B: Environmental 2012, 127, 371

[57] M.T. Paffet, J.G. Beery, S. Gottesfeld, J. Electrochem. Soc. 1988, 135, 1431

[58] X. Yu, S. Ye, J. Power Sources 2007, 172, 145

[59] B. Fang, B. N. Wanjala, J. Yin, R. Loukrakpam, J. Luo, X. Hu, J. Last, C.-J. Zhong, Int. J. Hydrogen Energy 2012, 37, 4627

[60] B. N. Wanjala, B. Fang, R. Loukrakpam, Y. Chen, M. Engelhard, J. Luo, J. Yin, L. Yang, S. Shan, C.-J. Zhong, ACS Catal. 2012, 2, 795

[61] B. Li, S. H. Chan, Int. J. Hydrogen Energy 2013, 38, 3338

[62] P. Brault, E. Neyts, Catalysis Today 2015, 256, 3

[63] H. A. Gasteiger and N. M Markovic, Science 2009, 324, 48

[64] J. P. Dodelet in N4-macrocyclic metal complexes (Ed. J. H. Zagal, F. Bedioni, J. P. Dodelet) Springer, New York, USA, 2006, Ch.3

[65] S. Baranton, C. Coutanceau, C. Roux, F. Hahn, J. M. Leger, J. Electroanalytical Chem. 2005, 577, 223 
[66] S. Baranton, C. Coutanceau, E. Garnier, J. M. Léger, J. Electroanalytical Chem. 2006, 590,100

[67] R. Othman, A. L. Dicks, Z. Zhu, International Journal of Hydrogen Energy 2012, 37, 357

[68] C. W.B. Bezerra, L Zhang, K. Lee, H. Liu, A. L.B. Marques, E. P. Marques, H. Wang, J. Zhang, Electrochimica Acta 2008, 534937

[69] E. B. Easton, A. Bonakdarpour, J.R. Dahn, Electrochem. Solid-State Lett. 2006, 9, A463

[70] E. B. Easton, A. Bonakdarpour, R. Yang, D. A. Stevens, J. R. Dahn, J. Electrochem. Soc. 2008, 155, B547

[71] Z. Yang, Z. Yao, G. Li, G. Fang, H. Nie, Z. Liu, X. Zhou, X. Chen, S. Huang, ACS Nano 2012, 6, 205

[72] K. Gong, F. Du, Z. Xia, M. Durstock, L. Dai, Science 2009, 323, 760

[73] P.H. Matter, E. Wang, M. Arias, E.J. Biddinger, U.S. Ozkan, J. Phys. Chem. B 2010, 110,18374

[74] P.H. Matter, U.S. Ozkan, Catal. Lett. 2006, 109, 115

[75] Y. Shao, J. Sui, G. Yin, Y. Gao, Applied Catalysis B: Environmental 2008, 79, 89

[76] D. Yu, E. Nagelli, F. Du, and L. Dai, J. Phys. Chem. Lett. 2010, 1, 2165

[77] O. Antoine, Y. Bultel, P. Ozil, R. Durand, Electrochimica Acta 2000, 45, 4493

[78] O. Antoine, Y. Bultel, R. Durand and P. Ozil, Electrochimica Acta 1998, 43, 3681

[79] S. Wu, P. Brault, C. Wang, Physica A 2011, 390, 2112

[80] J. Barroso, A.R. Pierna, T.C. Blanco, N. Ruiz, International Journal of Hydrogen Energy 2014, 39, 3984

[81] L. Xie, P. Brault, J.-M. Bauchire, A.-L. Thomann, L. Bedra, J. Phys D 2014, 47, 224004 
[82] A. Caillard, Ph. D. Thesis, University of Orléans (France) and Australian National University (Canberra, Australia), December, 2006

[83] M. Mougenot, P. Andreazza, C. Andreazza-Vignolle, R. Escalier, Th. Sauvage, O. Lyon, P. Brault, J. Nanoparticle Research 2012, 14, 672

[84] M. Mougenot, Ph. D. Thesis, University of Orléans (France), October, 2011

[85] S. Roualdès, M. Schieda, L. Durivault, I. Guesmi, E. Gérardin, J. Durand, Chem. Vap. Deposition 2007, 13, 361

[86] A. Ennajdaoui, S. Roualdes, P. Brault, J. Durand, J. Power Sources 2009, 195, 232

[87] V. Tripkovic, H. A. Hansen, J. Rossmeisl, T. Vegge, Phys. Chem. Chem. Phys. 2015, 17,11647

[88] S. Lankiang, M. Chiwata, S. Baranton, H. Uchida, C. Coutanceau, Electrochimica Acta 2015, 182,131

[89] A. Morozan, B. Jousselme and S. Palacin, Energy Environ. Sci. 2011, 4, 1238

[90] J. Berndt, H. Acid, E. Kovacevic, C. Cachoncinlle, Th. Strunskus, L. Boufendi, J. Appl. Phys. 2013, 113, 063302

[91] A. Felten, C. Bittencourt, J. J. Pireaux, G. Van Lier, J. C. Charlier, J. Appl. Phys. 2005, 98, 074308

[92] B. Ruelle, S. Peeterbroeck, R. Gouttebaron, T. Godfroid, F. Monteverde, J.-P. Dauchot, M. Alexandre, M. Hecq and P. Dubois, J. Mater. Chem. 2007, 17, 157

[93] B. Khare, P. Wilhite, B. Tran , E. Teixeira, K. Fresquez, D. Nna Mvondo, C.

Bauschlicher Jr., M. Meyyappan, J. Phys. Chem. B 2005, 109, 23466

[94] M. V. Naseh, A. A. Khodadadi, Y. Mortazavi, F. Pourfayaz, O. Alizadeh, M. Maghrebi, Carbon 2010, 481369

[95] Y. Shao, S. Zhang, M. H. Engelhard, G. Li, G. Shao, Y. Wang, J. Liu, I. A. Aksayc and Y. Lin, J. Mater. Chem. 2010, 20, 7491

[96] Q. Wang, X. Wang, Z. Chai, W. Hu, Chem. Soc. Rev. 2013, 42, 8821 
[97] L.G. Bulushevaa, A.V. Okotruba, A.G. Kurenyaa, H. Zhang, H. Zhang, X. Chen, H. Song, Carbon 2011, 49, 4013

[98] H.-G. Wang, Z. Wu, F.-L. Meng, D.-L. Ma, X.-L. Huang, L.-M. Wang, X.-B. Zhang, ChemSusChem 2013, 6, 56

[99] W. H. Shin, H. M. Jeong, B. G. Kim, J. K. Kang, J. W. Choi, Nano Letters 2012, 12, 2283

[100] M. Michel, J. Bour, J. Petersen, C. Arnoult, F. Ettingshausen, C. Roth, D. Ruch, Fuel Cells 2010, 10, 932

[101] D. Merche, N. Vandencasteele, F. Reniers, Thin Solid Films 2012, 520, 4219 